\title{
ESKIMOKULTUR, ARKÆOLOGI OG MUSEUMSSAMLINGER
}

\author{
Hans Christian Gulløv
}

I det folgende fortalles historien om den danske udforskning af Grønlands forhistorie, som den udviklede sig fra begyndelsen af dette arhundrede. Det er ogsa beretningen om retten til fortolkning af de arkaologiske data. Den akademiske konflikt mellom kilde og objekt satte dybe spor $i$ den danske grønlandsforskning og varede ved $i$ mere end et halvt arhundrede.

I begyndelsen af dette arhundrede blev den ukontrollerede indsamling af oldsager $i$ kolonien Grønland udsat for voldsom kritik. Det var opfattelsen blandt de grønlandske medlemmer af det sydgrønlandske landsråd, at den omsiggribende tømning af de hedenske grave for nedlagte gravgaver havde taget overhaind. Der ville efterhainden intet vare efterladt, som kunne fortelle kommende generationer i landet om forfadrenes redskaber og skikke, lod kritikken. Derfor blev det dengang foreslàet at oprette et museum til bevaring og sikring af Gronlands egen fortid. Forslaget skulle imidlertid henge $i$ luften $i$ mere end et halvt arhundrede, for det blev realiseret $i$ 1966.

I dag er dette en del af det grønlandske museumsvæsens historie, som i $1981 \mathrm{kul}-$ minerede med overdragelsen af hele kultursektoren til det grønlandske hjemmestyre, og tre år senere med nedsættelsen af Udvalget for det dansk-grønlandske Museumssamarbejde, hvorefter væsentlige dele af de grønlandske samlinger i København nu atter er tilbage i deres oprindelsesland.

Blandt synderne dengang stod især den danske embedsmandsstand for skud. Det var en almindeligt accepteret holdning, at hedenske grave ikke kunne være omfattet af samme respekt som en kristen gravlæggelse $\mathrm{i}$ indviet jord. Dette synspunkt var udbredt også blandt præsterne i landet, som siden midten af forrige århundrede førte an i undersøgelsen af de gamle grave. Knud Rasmussen noterede i sin dagbog fra Vestgrønland inden slæderejsen nordpå til polareskimoernes land, at han sammen med sine ekspeditionskammerater endevendte de gamle grave til stor bestyrtelse for de ledsagende grønlændere. Men inden da syntes markedet at være mættet - i 
88 hvert fald hvad angår modtagelsen af de indleverede samlinger til kongerigets officielle museum, Nationalmuseet - og da lægen i Jakobshavn i slutningen af forrige århundrede opsøgte museet for at afsætte sin systematisk indsamlede og ordnede samling af oldsager fra Disko Bugt området, blev ønsket afvist af Sophus Müller med den begrundelse, at museet nu havde fuldt ud dækkende samlinger fra landet. Samlingen blev herefter solgt til Sverige, og er endnu i dag af stor betydning som dokumentation for Grønlands forhistorie. Der var ikke meget tilbage i denne del af landet, da kunstneren Ossian Elgström, præsten Hother Ostermann og lederen af Arktisk Station Morten Porsild i 1915 plyndrede grave i Disko Bugt, og førstnævnte i sin iøvrigt fremragende rejsebog beskrev handlingen som videnskabelig.

Blandt periodens systematisk indsamlede genstande var den etnografiske dokumentation af landets befolkning et middel til forøgelse af samlingerne. Det var efter oprettelsen i 1878 af Kommissionen for Ledelsen af de geologiske og geographiske Undersøgelser i Grønland, at indsamlingerne blev målrettede og især fandt sted på østkysten, som dengang var forholdsvis ukendt. Premierløjtnant Gustav Holms beretning om konebådsekspeditionen til Ammassalik og mødet med de sidste østgrønlændere i 1880erne er blevet en etnografisk klassiker, og de hjembragte samlinger er et vigtigt referencemateriale i både museologisk og forskningsmæssig henseende. Herefter gennemførtes indtil 1908 tre store videnskabelige undersøgelser i Østgrønland, som nu var blevet berejst og beskrevet i hele sin udstrækning, med Danmark-Ekspeditionens hjemkomst dette år. Ansvaret for de foretagne indsam- linger og arkæologiske undersøgelser havde i felten været overdraget marinens folk, mens den egentlige beskrivelse af de hjembragte genstande blev foretaget af museumsfolk.

Hermed var vejen banet for en egentlig arkæologisk udforskning af Grønlands forhistorie. Denne blev fra 1929 lagt i hænderne på Therkel Mathiassen, som fra 1921 til 1924 havde arbejdet som arkæolog på Knud Rasmussens Femte Thule Ekspedition til Arktisk Kanada. Det blev herefter arkæologien, som stod øverst på Nationalmuseets forskningsplan. Omfattende udgravninger flere steder i det arktiske Nordamerika havde siden 1930erne vist en betydelig tidsdybde, hvor flere palæoeskimoiske kulturer havde eksisteret. At søge deres indflydelse i Grønland blev en langsigtet forskningsopgave, som danske arkæologer har stået for.

Men inden da var registreringen af de tidligere indkomne samlinger udelukkende en isoleret museumsopgave. Her indførtes genstandene efter vedtagen norm under følgende fire hovedemner: gudedyrkelse, våben, husgeråd og dragter. Ud fra disse overskrifter kunne kulturen beskrives. Det var med andre ord de definerede kategorier, som blev nøglen til kulturforståelsen, og den øgede mængde indkomne oldsager, hvis ukendte og til tider fragmentariske former forblev ubestemmelige, måtte efter et valg placeres i de anførte kategorier eller forsynes med et spørgsmålstegn.

Da de første større samlinger fra Østgrønland skulle beskrives og efterfølgende publiceres $i$ den internationale serie Meddelelser om Grønland, valgte Kommissionen en person udenfor museumsverdenen til dette arbejde. Det drejede sig 


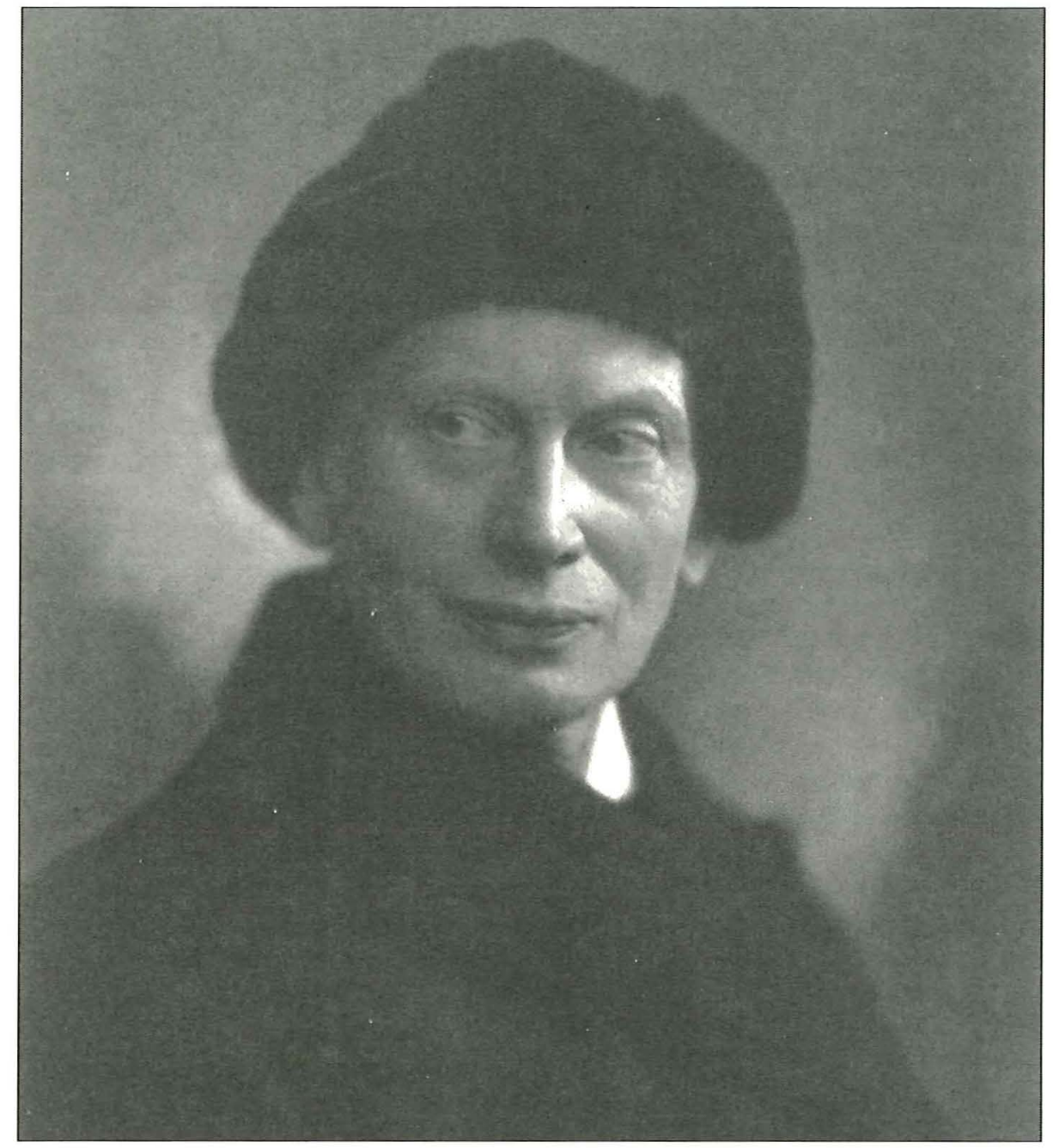

Aterlierfoto af William Thalbitzer i vinterudstyr $i$ Kobenhavn. Foto Elfelt, Institut for Eskimologi. Fra Tusaat/Forskning $i$ Gronland 2-3/95.

On my return home in 1906 from Ammassalik, ... I was called upon ... to prepare not only the results of my own journey, but also a description of the Amdrup collection ... I hesitated at first to undertake work of a kind which lay outside the special line of study I had hitherto pursued. On the other hand ... This interesting collection surely deserved a better fate than to be forgotten. Further than this, in my capacity of linguist, I was sensible of the advantage of obtaining a better insight into the forms assumed by the material culture of the East Greenlanders; for changes in the implements often run parallel to changes in the language, and the Ammassalimmiut, in fact, have their own particular designations for many of their Eskimo implements and utensils. An exact knowledge of the objects and their modifications will always come in useful in studying a people's linguistic designation of these objects.

During my two journeys to the West and East coast of Greenland, I had had an opportunity of acquiring a first-hand knowledge of the implements and mode of life of the Greenlanders. When I was now shown the highly weathered objects from North East Greenland which lay on two tables in the building of "Det kgl. Danske Videnskabernes Selskab", arranged and docketed by Amdrup according to the localities where they were found, they presented to me a familiar appearance. The lifeless objets seemed to me in their dumb language to call upon me to furnish a solu- tion to the following problem: - In what relation do these objects, which testify to a primitive culture of seemingly great antiquity in the arctic regions of East Greenland, stand to the present Eskimo culture which you know from the southern part of the same coast? Is there in the peculiar forms of implements and the peculiar designations of the Ammassalimmiut any reminiscence of a culture which can be interpreted only in the light of this northern culture? (Thalbitzer 1909). 
90 om genstande indsamlet 1898-1900 under Carlsbergfondets Ekspedition til Østgrønland og om Gustav Holms store samlinger fra 1884-85 til Ammassalik, som begge skulle udkomme på engelsk. Løsningen af opgaven blev overdraget sprogforskeren William Thalbitzer. Han havde kun den nøgne genstand foran sig på sit skrivebord, da han gik i gang; men til gengæld opnået en veludviklet sans for det eskimoiske sprog efter to overvintringer $\mathrm{i}$ både Vest- og Østgrønland. Metoden hentede han fra sit eget fagområde og antog, at ændringer i udformningen af redskaber forløb parallelt med ændringer i sproget. En nøjagtig viden om genstandene og deres variationer ville således altid være brugbar for et studium af en befolkningsgruppes sproglige betegnelser for disse genstande.

Thalbitzer sammenlignede ikke arkæologiske typer men genstandenes betydning $i$ en social og kulturel sammenhæeng og forudsatte således en kulturel kontinuitet mellem geografisk adskilte egne, som arkæologien først langt senere tog alvorligt. Østgrønland var i denne henseende en interessant udfordring for ham, fordi den tilbageværende befolkning ved mødet med europæerne få årtier inden blev beskrevet som «den sidste isolerede stamme», der måtte leve med blodhævn og kannibalisme. Den mundtlige tradition berettede om tidligere møder mellem folk fra nord og syd, som han mente at kunne finde beviser for i den materielle kultur, i befolkningens levevis og i deres sprog. Denne endnu levende tradition var opstået "ved giftermål og socialt fællesskab, som havde sammensmeltet disse grupper til en helhed", og han sammenfattede i 1912 sine undersøgelser i følgende konklusion:
"Af denne sammensmeltning fremstod Grønlands mest fremtrædende, mest komplekse og artistiske eskimoiske samfund".

Hermed berørte han direkte det arkæologiske og etnografiske grundproblem, som ligger i spørgsmålet om hvilket sprog, der egentligt beskriver virkeligheden. Han var klar over, at det videnskabelige sprog forudsatte en logisk orden, der kunne tilfredsstille samtidens krav om en præcis beskrivelse af kulturens genstande, men indså samtidig, at befolkningens egne beskrivelser bragte uorden i den videnskabelige logik.

De omfangsrige publikationer som tilsammen fyldte mange hundrede trykte sider blev udsat for en voldsom kritik fra Nationalmuseet fremført af inspektør Thomas Thomsen og sanktioneret af Sophus Müller. De væsentligste indvendinger gik på mangelfulde beskrivelser, der primært skyldtes de hindringer, Thalbitzer blev stillet overfor ved arbejdet på museet, hvor han ofte havde måttet beskrive genstandene gennem montrenes glas, og dernæst på sammenblandingen af kategorier. Det var dengang vanskeligt at acceptere, at det åndelige kunne udtykkes i det materielle og omvendt. Dette stred mod det gældende videnskabsteoretiske synspunkt, som definerede en kultur på en evolutionistisk skala, der gik fra det simple til til komplicerede. At kalde en grønlandsk kultur for den mest komplekse var uvidenskabeligt og en provokation.

«De livløse genstande synes med deres tavse sprog at henvende sig til mig med en løsning på følgende problem: ... Er der i genstandenes særlige former og i ammassalimmiuts særlige betegnelser noget levn eller nogen erindring om en kultur, som udeluk- 
kende kan fortolkes i lyset af ammassalimmiuts egen kultur?»

Problemstillingen formuleredes, da Thalbitzer sad med den første samling foran sig, og er interessant, fordi den forudsætter en historisk kontinuitet, som det synes muligt at beskrive, hvis man også hører befolkningens egen mening om den sag. Den mening havde han taget stilling til og fået at vide, at arkæologien tilhørte arkæologerne og etnografien tilhørte etnograferne. Næste gang Thalbitzer satte sine ben på Nationalmuseet var som højt respekteret ærespræsident for den internationale amerikanistkongres, der i 1956 blev afholdt i København.

Jeg har med denne beretning om en af de første videnskabelige beskrivelser af arkæologiske samlinger fra Grønland peget på det evigt gyldige problem, som vi konfronteres med i vort daglige virke: Hvem ejer fortiden? Fra kolonitidens ringe eller manglende forståelse for de koloniseredes egne vidnesbyrd om den nære og fjerne fortid til den videnskabelige ejendomsret til fortolkning og forståelse er der egentlig ikke så langt. I dag vil vi efterrationalisere og sige, at havde vi ikke samlet ind - uanset efter hvilke kriterier - så havde der jo intet været at give tilbage. Men fik vi også lyttet til og opfattet «de livløse genstande med deres tavse sprog»? Det ligger langt fra en videnskabelig metode at besvare et spørgsmål af denne karakter, hvis vi ikke, som Thalbitzer foreslog, hører befolkningens egen mening om den sag.

Kombinationen af mundtlig tradition og arkæologi er en udfordring for forskningen. I Grønland som i det øvrige eskimoiske Arktis har fortælletraditionen været levende langt op i dette århundrede og indgår som et aktiv i næsten enhver arkæologisk undersøgelse. Jeg blev selv uforvarende traditionens midtpunkt, da jeg i 1968 skulle foretage en undersøgelse af en næsten tre meter tyk møddingsaflejring i en lille bygd på vestkysten. Formålet var dengang at påvise den eskimoiske stenalder, dvs. den 3-4000-årige såkaldte Saqqaqkultur, nederst i de mægtige aflejringer på denne lokalitet. Men inden da skulle vi fjerne det tykke græsdække, hvorved nogle mørnede rester af en trææske og en lille samling farvestrålende glasperler kom til syne. Udgravningen blev fulgt af bygdens børn men også af det gamle kateketpar på stedet. Da perlerne dukkede op, lød den herligste latter fra den gamle kvinde. Jeg havde fundet de perler, hun havde tabt på vej hjem fra butikken ud til sit hus på pynten, hvor hun dengang boede, og hvor vi nu gravede. Det var sket 45 år tidligere. Huset var blevet forladt i 1936, men jeg havde fået tingere $\mathrm{i}$ tale, og mere end det. Jeg fik skabt kontakt til en lokalhistorisk kilde, som jeg i den efterfølgende tid kunne øse af $\mathrm{i}$ rigt mål. Parrets viden var legendarisk. Jeg skiftede på én gang mit forskningsmæssige interessefelt fra at være forhistorie til at blive etnohistorie. Fra denne platform kunne man bogstaveligt grave sig tilbage $\mathrm{i}$ fortiden og hele tiden få tingene i tale. 300 år i ubrudt linie. Det var længere tilbage end de skriftlige kilder kunne dokumentere. Den ældgamle eskimoiske fortælletradition var ikke blot et middel til underholdning men viste sig også i genskabelsen af det rum, hvori begivenhederne havde udspillet sig. At fortælle og at tale er at se. Det havde Knud Rasmussen også fået at vide i 1920erne i Arktisk Kanada. 
92 Men fik vi nu det hele med, da vi gravede og samlede ind? Både ja og nej. Naturligvis ikke det hele, fordi vi kun samlede stumperne og affaldet op. Men det har heller ikke været formålet. Derimod fik vi fat $\mathrm{i}$ betydningen af de efterladte genstande, og vi fik tilmed fortalt i hvilken sammenhæng, vi skulle søge deres oprindelse. Noget vidste vi i forvejen, noget kunne vi slutte os til, men væsentligst af alt var dog, at vi hørte, hvad de havde at sige til os, og vel at mærke sagt af de mennesker, hvis fortid de var en del af.

Således bliver et af kravene til kulturformidlingen i det grønlandske tilfælde, når afstanden mellem mennesket og naturen er blevet historie, at fastholde traditionen, som kan få tingene i tale. Og det er skæbnens ironi, at det blev museumssamlingerne, der startede så ukontrolleret, som skal løse denne opgave.

\section{NOTE}

Citatet s. 89 er fra: Thalbitzer, W: Ethnological description of the Amdrup Collection From East Greenland, 1909, fra Meddelelser om Gronland, otte og tyvende Hefte, Kjøbenhavn 1909.

\section{SUMMARY}

Eskimo culture, archaeology and collections

At the turn of this century, uncontrolled collecting of Eskimo objects by Europeans became a threat to the Greenlandic culture. "Damaging the Eskimo culture by spoiling heathen graves". That was the opinion expressed by members of the political board of South Greenland. A proposal was then made for building a museum which was realized more than half a century later.

From 1929, systematical archaeology was carried out in the country. Before that time, naval officers did the archaeology while museum employees had to take care of the descriptions. Therefore, it was a provocation to Danish museum circles that the first scientific description of the larger collections from East Greenland, to be published in the national monograph series Meddelelser om Gronland, were left entirely to a linguist, William Thalbitzer. But for the latter it became a challenge. He learned how to listen to the objects as he listened to the voice of the East Greenlanders. That way of scientific thinking made no sense to scientific circles in Denmark at that time, and Thalbitzer's work was neglected until 1956 when as an esteemed honorary chairman of the International Congress of Americanists he entered the Danish National Museum for the first time since the beginning of the century.

The story of Danish research in Eskimo culture raises the problem of ownership to the past. The attitude of the colonists towards the opinion of the colonized Greenlanders about their past and the scientific ownership to interpretation and understanding make no difference in etno-centrism. It is only in recent decades that archaeology in Greenland has adopted the guideline pointed at by Thalbitzer when doing cultural historical research: listening to the Greenlanders to learn from their traditions.

Hans Christian Gullov, seniorforsker ved Etnografisk Samling, Nationalmuseet. Studeret antropologi, arkaologi, geografi og eskimologi ved Kobenhavns Universitet. Disputats om Gronlands etnohistorie. Fagredaktor af Meddelelser om Gronland, Man \& Society. Feltarbeider i Gronland siden 1968.

Adr. Etnografisk Samling, Nationalmuseet, Fredriksholms Kanal 12, DK-1220 Kobenhavn K Fax $+45-33473320$

e-mail: es-hcg@palais.natmus.min.dk 